\title{
The status and practice of forestry in Brazil in the early 1990s
}

\author{
by William J. Ondro ${ }^{1}$, Laércio Couto ${ }^{2}$ and David R. Betters ${ }^{3}$
}

\section{Introduction}

The steadily increasing demand for long-fiber pulps and the successful substitution of these products with pulp mixes has led in the last few years to an increased international interest in industrial technologies for manufacturing these products and in the companies producing them in various countries. In Canada such interest has been concentrated on the use of aspen for pulp mixes. Elsewhere in the world, particularly in Brazil, interest has centered on the production of eucalyptus pulp.

Brazil (Fig. 1) is the fifth largest country in the world after Russia, Canada, the United States and China, with an area of 8.5 million $\mathrm{km}^{2}$ and 150 million inhabitants, $42.5 \%$ of whom are concentrated in the southeastern states. Most of the northern part of the country is equatorial, while the balance is generally tropical with subtropical parts in the south. The topography varies between and within regions but most of the country is represented by plateaus and flat areas (the savanna-like regions). The highest elevation in Brazil is Pico da Neblina in northern Amazônia, which is $3000 \mathrm{~m}$ above sea level.

The Brazilian economy was among the ten largest in the world in 1994, with a Gross National Product of US \$422 billion. Brazil's ability to increase its world market share of pulp by using wood from the short-rotation eucalypt plantations is notable. Following new developments in world pulp product markets, the extensive and productive eucalypt plantations of Brazil now rank first in supplying wood of this genus.

\section{Forest Resources}

Brazilian native vegetation may be divided into the following groups: (1) the Amazonian rain forest, covering all the Amazon river basin which is considered the largest continuous stretch of tropical forest in the world; (2) the Atlantic forest covering the coastal mountains and the inland plateau; (3) the Araucaria forest, presenting a more temperate characteristic and occurring in the southern part of the country; (4) the Cerrado, a savanna-like region with low-density forest vegetation consisting of scattered and crooked trees; (5) the Caatinga, composed of species adapted to drought and long, dry periods; (6) the Pantanal, a swampy land in the central and western parts of the country with very rich fauna and flora; (7) the Pampas, which are native grasslands located in the extreme south of the country and (8) the Mangues, the shoreline vegetation represented by manglars and mangroves along the Brazilian coast (Suchek 1991).

The Amazonian forest used to cover $40 \%$ of the country's territory but today it covers only $36 \%$. Vegetation is highly heterogeneous, with some 200 mature trees and about 200 different

\footnotetext{
${ }^{1}$ Research economist, Canadian Forest Service, Northwest Region, Northern Forestry Centre, 5320-122 Street, Edmonton, Alberta, Canada T6H3S5.

${ }^{2}$ Professor, Departamento de Engenharia Florestal, Universidade Federal de Viçosa, 36570-000, Viçosa, Minas Gerais, Brazil.

${ }^{3}$ Professor, Department of Forest Sciences, Colorado State University, Fort Collins, Colorado, 80523 , U.S.A.
}

species in a single hectare, resulting in lumber operations that are economically difficult. The low fertility of the soils, the severe, climatic conditions with high temperature and humidity and the occurrence of tropical diseases make it difficult to open this frontier for other land uses. As a result, the forest is still standing with perhaps as much as $90 \%$ of the original cover intact.

The Atlantic forest once covered $10 \%$ of all Brazilian territory, and extended from Pernambuco to Rio Grande do Sul in the coastal region of the country, but was almost entirely cleared for agriculture and cattle raising. Today it covers only $1 \%$ of Brazil.

The Araucaria forest was practically eliminated in the early part of the century because of harvesting for lumber exports. The most important commercial species is Araucaria angustifolia, also called Paraná pine, which is a source of high quality lumber. In association with Paraná pine, there were a few high-quality hardwoods that were intensively exploited to provide space for agriculture and pastures. The forest used to cover $5 \%$ of the entire country, but today only $10 \%$ of the original forested area remains.

The Cerrado savanna occupies Brazil's central, western and southern regions. Once $20 \%$ of the Brazilian territory, it now covers only $12 \%$ of the country. The southeastern Cerrado region is one of the most important for eucalypt culture in Brazil because charcoal and the rich deposits of iron ore support local steel manufacturing, cement companies, and pulp and paper plants that are vital components of the national economy. More than $70 \%$ of the wood grown in the state of Minas Gerais is used for charcoal production, with the balance diverted to pulp and paper, lumber and other products. The interest in this region by forest companies is related to the availability of large tracts of inexpensive, flat to gently rolling land suitable for mechanized practices (Ayling and Martins 1981). Until recently most of the charcoal used by the iron and steel-making industries in the southeastern part of Brazil was provided by the Cerrado area. Today, along with the large short-rotation forest plantations, there are large agricultural crop plantations of soybeans, rice, corn, sorghum, sugar cane, citrus and coffee in the Cerrado area. These are very advanced agricultural ventures, providing high quality products for export. Cattle raising for beef production is another activity that is well developed in the Cerrado area.

Following the large scale devastation of forest resources in the southern part of the country, an effort was made to find tree species having rapid growth. The railroad systems need for fuelwood brought the eucalypts from Australia which became the most popular species available. Concern with lumber uses and reversal of the quick depletion of the Araucaria forest, caused pines to be introduced from southern U.S.A., Mexico, Central America and the Caribbean countries (Suchek 1991).

In 1965, a new version of the Brazilian Forestry Code was approved, which allowed development of new forests by using fiscal incentives for the establishment of man-made forests. This code was the key to the growth of the Brazilian forest sector. In 1966, the federal government passed Law 5106/66 


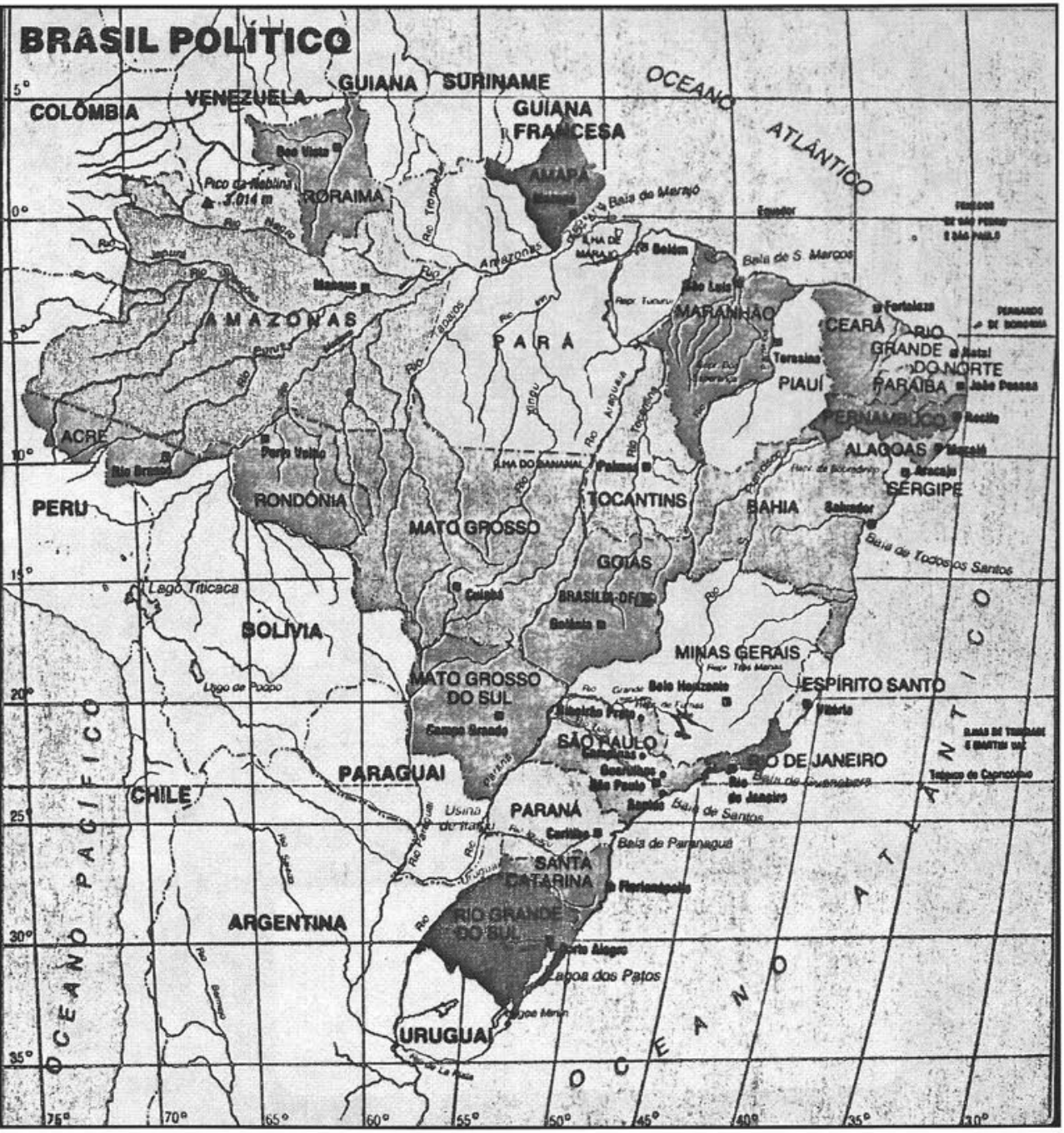

Figure 1. Map of Brazil.

that allowed individuals and companies to use $50 \%$ of their income tax payment for reforestation purposes. As a consequence of this law, the planted forest area in Brazil soared from 470,000 ha before the fiscal incentives were introduced to 6.2 million ha in the 1990s, of which 3 million ha were in eucalypt plantations (Siqueira 1990). This paper will focus on the eucalypts because of their greater importance relative to pines and other introduced species in Brazil.

\section{Eucalypt Plantations}

A milestone in the establishment of intensive and advanced short-rotation silviculture in Brazil was discovering the feasibility of using eucalypt wood for pulp and paper production in the 1970s (Soresini 1993). The country became the world's leader in eucalypt plantations. Along with all benefits accruing from the short-rotation plantations, however, there was also a wave of criticism, mainly from individuals and organizations concerned with possible harmful effects the eucalypts might have on the environment and on the social welfare of rural communities.

The southeastern region of Brazil, comprised of the states of Minas Gerais, Espírito Santo, Rio de Janeiro and São Paulo, is one of the most important for the country's forestry sector. In this region are located the most extensive eucalypts plantations in Brazil. These are a source of raw material for the region's iron, steel, cement, and pulp and paper industries.

Eucalypt plantation establishment in Brazil, particularly in southeastern region, experienced enormous growth during the 1970s and 1980s. Termination of fiscal incentives in 1987, however, led not only the southeastern firms but all Brazilian forest industries to search for alternatives to reduce plantation costs and the cost of their wood supply. After 1984, cost reduction became a key management goal of the pulp and paper manufacturers and charcoal-based cement and steel industries. During that time there was mounting criticism concerning large-scale eucalypts and pine plantations and their adverse impacts on biodiversity. These criticisms also contributed to the search for alternative land uses.

One of the best reports on the growing of eucalypts on short-rotation in Brazil in the 1970s and early 1980s was that done by Ayling and Martins (1981). More recently the role of the planted forests in the pulp and paper industry was discussed by Suchek (1991), who also gave some insights on the silvicultural and management aspects of the country's eucalypt plantations in the 1980s and early 1990s. Betters et al. (1991) also described and discussed in detail the operations associated with the short-rotation eucalypt plantations in the late 1980s and early 1990s. As described in this paper, however, Brazilian forestry practices has been changing rapidly. 


\section{History}

It is difficult to determine exactly where and when the first eucalypt species was planted in Brazil. Early records show that in 1824 eucalypt was planted at the Botanical Garden of Rio de Janeiro by the Garden's director Frei Leandro do Sacramento (Sampaio 1975). No one, however, will deny that it was Edmundo Navarro de Andrade who in 1904 started the first scientific work dealing with the introduction of Eucalyptus species. He established the first eucalyptus plantations in Brazil. After earning his diploma as an agronomist in Coimbra, Portugal, Navarrode Andrade brought some seeds of Eucalyptus globulus to Jundia, São Paulo, where he planted them with some other exotic and native tree species. At that time, Andrade was working for the Paulista Railroad Company and his assignment was to provide firewood for the company's steam-powered engines and sleepers. In a few years the eucalypt test plots outgrew those of all the other species, encouraging Andrade to import more seeds of different species of this genus for testing in São Paulo. As a result of his efforts, a total of 217 different species of Eucalyptus were introduced into Brazil (Spinelli 1993).

From 1909 to 1965 about 470000 ha of Eucalyptus species were planted by government-owned and private industries. Eighty percent of these plantations were in the state of São Paulo. The eucalypts were introduced as a substitute for native woods in supplying firewood to the railroad companies. The remaining native forests were further away from the consumption centers. Other energy sources such as coal were not available in Brazil and had to be imported at a high cost. In 1948 the company Cia Belgo-Mineira established the first eucalypt plantations in Minas Gerais to provide wood for charcoal products to be used by the local charcoal-based iron and steel-making industry (Magalhães Neto 1993).

In the 1970s large eucalypt plantations (stimulated by the fiscal incentives for reforestation) were spread over the states of São Paulo, Minas Gerais, Espírito Santo, Bahia, Mato Grosso do Sul and Rio Grande do Sul, and some other regions of the country. At that time, criticism mounted in Brazil about the alleged harmful effects of eucalypts on the environment. Eucalypts alledgedly had adverse effects on the soil, the water cycle, wildlife and local vegetation.

\section{Silviculture and Management}

Today most Brazilian forest industries are not acquiring land to establish new plantations. The steady increase in the price of land and pressure of environmentalists caused some countries to pass laws that prohibit forest industries from planting eucalypts on newly acquired land in their jurisdiction. This has forced companies to change their traditional policy. They now establish new plantations mostly on previously harvested areas and rely on their ability to increase forest productivity and on forest farmer programs to increase the availability of wood supply.

Most of the industries today have changed from very intensive agriculture-like site preparation used in the 1970s and 1980s, to a minimal cultivation technique to avoid soil erosion and nutrient losses. Slash burning, once a very common practice to help eliminate the original vegetation, is not used any more. Typically the vegetation is either left on site or incorporated into the soil to improve organic matter content and promote nutrient cycling. In some states like São Paulo, there are laws that prohibit the use of fire as a tool for site preparation in both agriculture and forestry.
Instead of harrowing and ploughing the soil as done in the past, most forest industries use herbicides to eliminate the natural vegetation; this is followed by furrowing of the soil in lines that are 3 to $3.5 \mathrm{~m}$ apart. Furrowing breaks up the superficial compacted layer of the soil in most of the areas to be planted, allowing better soil absorption of rainfall and a faster growth of seedlings. Seedlings are planted in the furrows from 2.5 to $3.0 \mathrm{~m}$ apart, receiving an initial (NPK) fertilization of $120 \mathrm{~g}$ seedling $^{-1}$. Planting is not restricted to the rainy season because of the regular use of irrigation at planting time. The nutrient requirements of the various eucalypt species are well known and fertilization is done according to local specifications to match needs of the genetic material and site quality.

Seedlings are not grown in polyethylene bags as they were in the 1970s. Today they are grown in dibble tubes, using vermiculite or sometimes a mixture of vermiculite, ground charcoal and compost as substrate. Most of the companies use vegetative reproduction to produce seedlings from root cuttings, which leads to homogeneous and highly productive clonal plantations (Fig. 2). A percentage of the total planting is from sexually produced seedlings derived from genetically improved orchards. The country is now a net exporter of genetically improved eucalypt and pine seeds. Among the best genetic material produced by the Brazilian companies is the hybrid Eucalyptus urograndis, which is a cross between Eucalyptus urophylla and Eucalyptus grandis. Hybrids are preferred for the JARI company's plantations in the Amazon region.

Weeding is mostly done with the use of herbicides applied just before planting then later during the early stage of stand establishment (4 to 8 months) (Figs. 3 and 4 ). Two years marks the end of the juvenile growth stage of eucalyptus plantations and no more weeding or tending is necessary (Fig. 5). Most potential problem insects are controlled by natural enemies produced in university or forest industry laboratories. Pesticides are rarely used, although aerial spraying was a common practice in the past. Diseases caused by fungi are controlled by using clones, hybrids and species that are resistant to them. A recent law restricts the use of the Dodecachlor insecticide, which was used extensively by the forest industries to control leaf-cutting ants and termites. A new product based on sulfuramid was developed, however, and it is already available on the market.

Rotation age has been kept to five to seven years, but harvesting operations (Figs. 6,7 and 8) have switched from a laborintensive cultivation in the 1970s and 1980s to more mechanized systems. Through the joint ventures of Brazilian and international companies, equipment was developed specifically for the short-rotation eucalypt plantations. The increasing social costs of labor in Brazil (contrary to the 1970s and 1980 s) is causing very intense mechanization of every possible forest operation, and a tendency to use hired contractors to establish plantations, harvest trees and haul them to the mills. Debarking is commonly done in mill yards. A percentage of the total amount of bark is used for energy production to supply mills and the balance is left to decompose and recycle.

Because of decreasing production from one cycle to another and the availability of new and improved genetic material, coppicing has not been used as frequently as in the past. Most of the forest industries today prefer to renew their plantations after the first harvesting. To avoid sprouting of the stumps, sites are sprayed with herbicides or simply covered by a layer of soil during site preparation. 


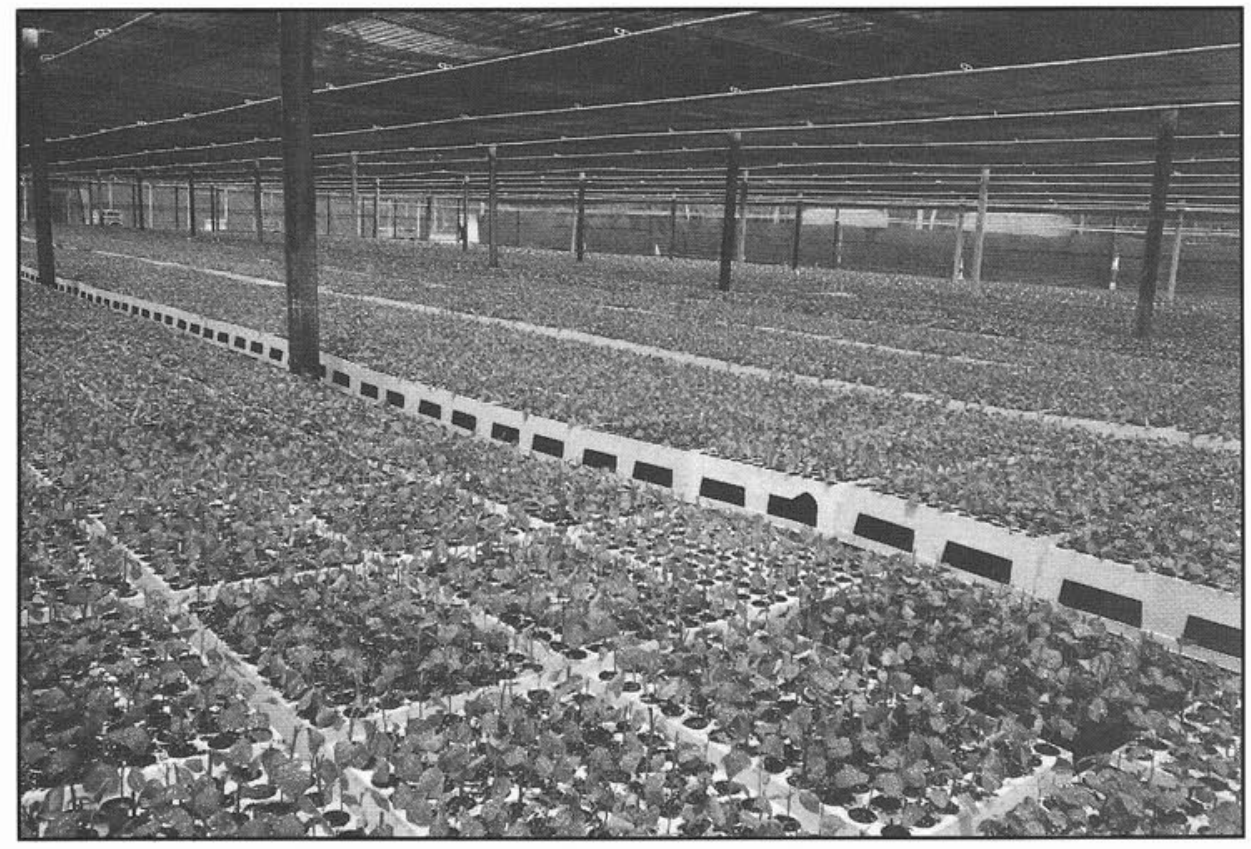

Figure 2. Eucalyptus seedling production by root cuttings in Aracruz, State of Espirito Santo.

\section{Environmental Issues}

During large-scale plantation development there was a lack of educational and scientific programs to monitor the silvicultural and ecological aspects of eucalypt plantations (Reis and Reis 1993). Most program efforts were devoted to enhancing timber production, and little attention was paid to the impacts of the newly established plantations on the environment. The lack of sound scientific information, in combination with poor use of the resources derived from fiscal incentives by some individuals and forest companies, the failure of some eucalypt plantations and the "exotic" characteristic of that genus in Brazil, set the framework for an anti-eucalypt campaign in the country. This campaign still continues today and gained some political overtones not known to agricultural crops such as soybeans, coffee, and sugarcane.

Criticism of eucalypt plantations that they lead to a diminished rainfall in their area of influence. In fact, the most significant hydrologic effect of a eucalypt plantation, as well as any other tree plantation or forest cover, is the interception of rainfall. A portion of the rainfall reaches the ground, while some remains in the canopy and is lost by direct evaporation (Lima 1993). The total loss of water by canopy interception is equal to the sum of the evaporation that occurs during rainfall and the evaporation that occurs after the rainfall from the water retained in the tree crowns. In the tropical regions, because precipitation is likely to be heavy and occur over a very short period, losses during rainfall are smaller than losses after precipitation. Each forest canopy has the capacity to store or hold water, which can be measured by using a leaf area index. The leaf area indexes of some eucalypt species are typically smaller than those of other forest species; this may lead to a lower total interception by those eucalypts when compared to other forest cover (Gash 1979). A review of the literature and data available from Brazil and other parts of the world suggests that on average the

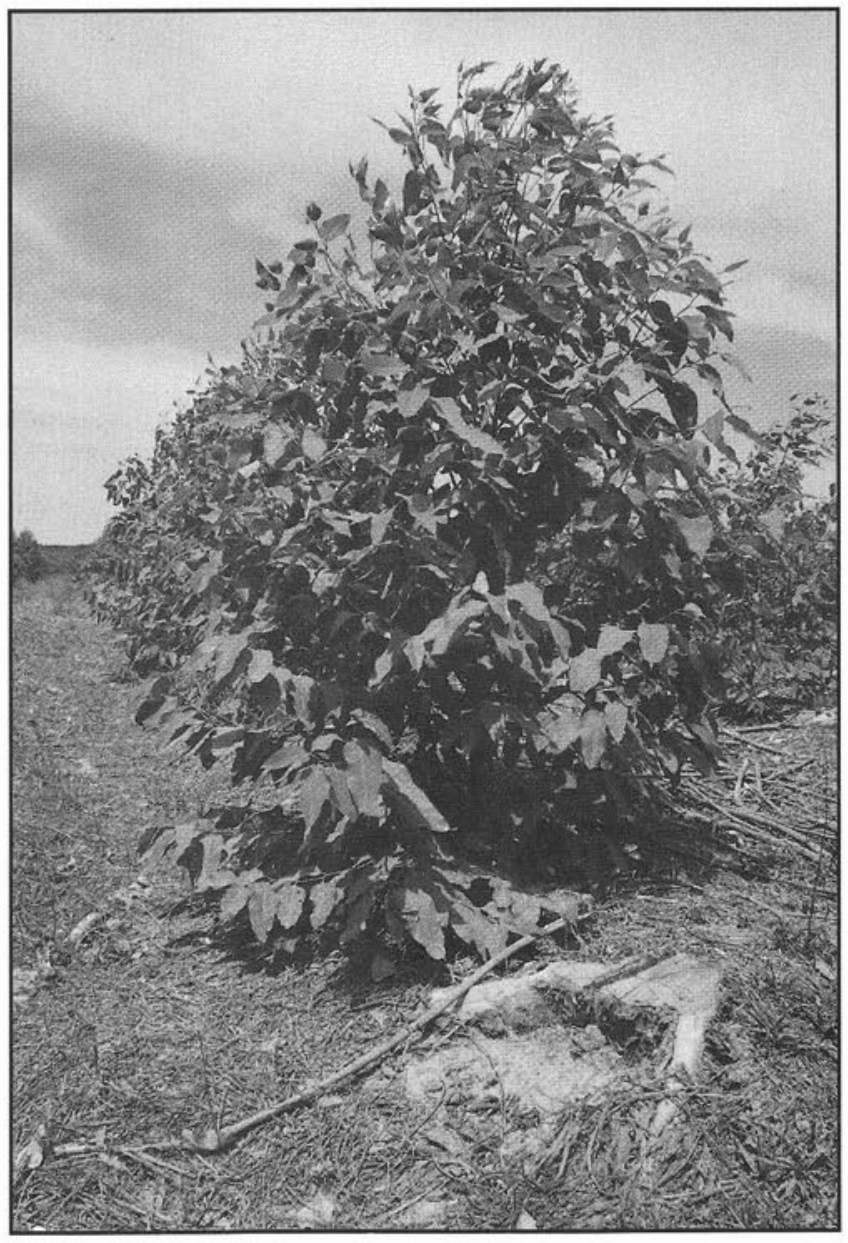

Figure 3. Six-month-old eucalyptus plantation in Sao Mateus, State of Espirito Santo. 


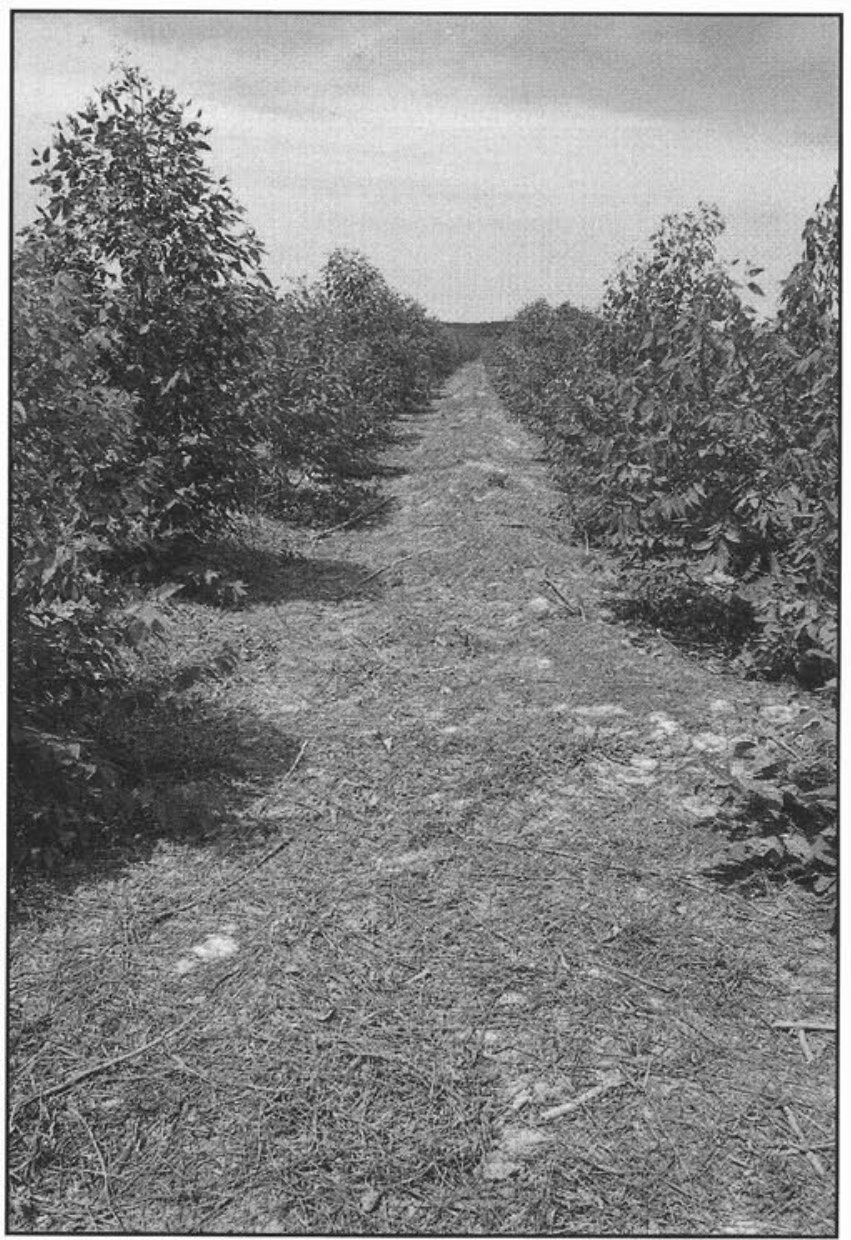

Figure 4. Six-month-old eucalyptus plantation in Sao Mateus.

water interception loss by eucalypt plantations is less than that of other tree plantations or native forests (Lima 1993).

Eucalypt plantations are also sometimes blamed for not providing adequate soil protection. This lack of protection can lead to less water infiltration and greater runoff and result in soil erosion and watershed sedimentation. This was probably true in the 1970s when site preparation for establishment of eucalypt plantations was similar to the system used for agricultural crops. At that time the vegetation was burned and the soil ploughed and harrowed. This exposed the soil to rainfall for at least the first six months after planting, during which time the seedlings were growing and their crowns had not covered the area. In 1994, silvicultural practices have essentially eliminated the use of fire, as well as operations such as ploughing and harrowing. These practices have been replaced by soil preparation in strips or by furrowing at a 3-m spacing with seedlings planted every 2 to $3 \mathrm{~m}$.

Watersheds covered by natural eucalypt forests in Australia produce good quality water (Hatch 1976). The most positive effect of the forest cover on water quality in a watershed occurs during rapid tree growth (Charley and Richards 1983). This indicates that eucalypt plantations in Brazil may have a beneficial effect on water quality since they have a very fast growth rate and a short rotation. The substitution of the forest cover by pastures and agricultural crops will normally promote a change in the water quality and water balance. The water often

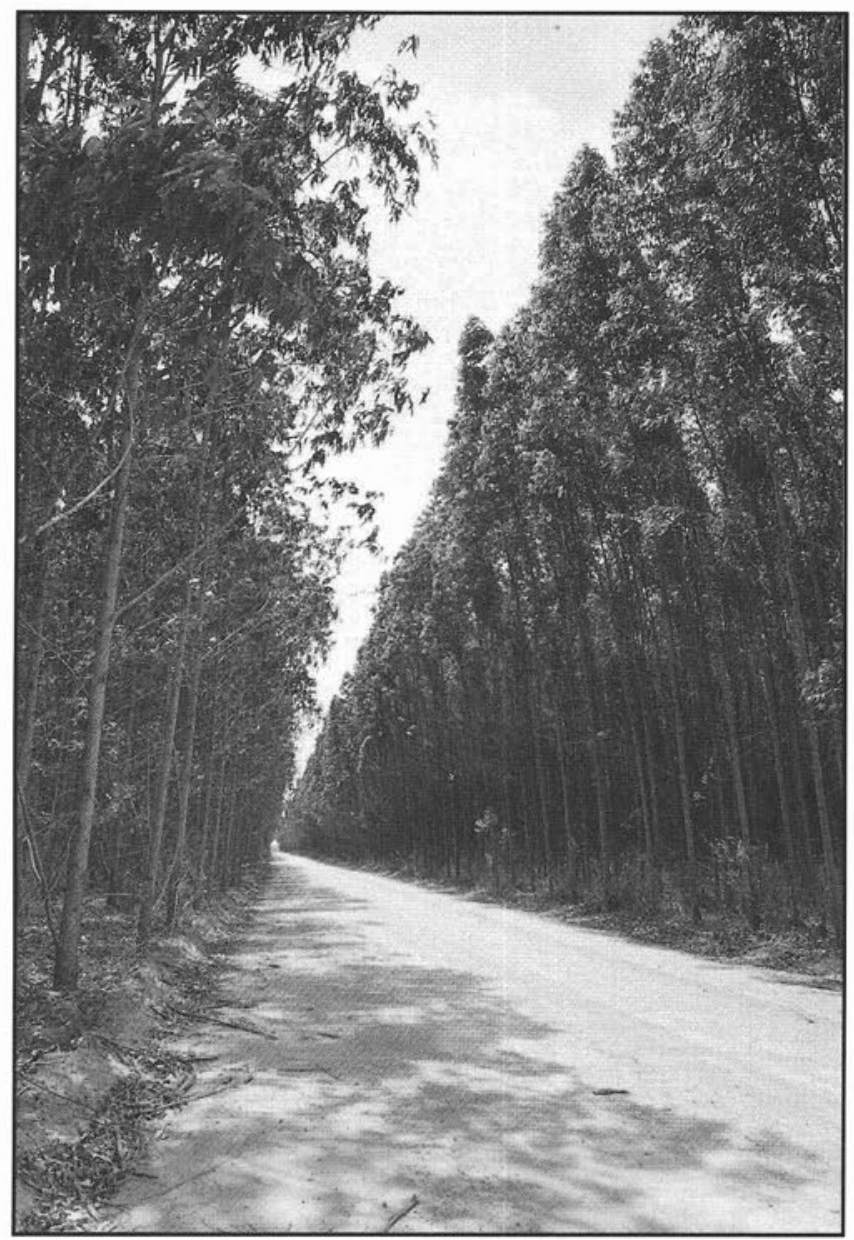

Figure 5. Two-year-old eucalyptus plantation in Sao Mateus.

becomes saltier. However, reforestation of the area will likely bring it back to the initial condition with time (Borg et al. 1988). It is therefore likely that establishing forest plantations can improve the watershed's condition. Care must be taken, however, as inadequate site preparation, clearcuts, fertilization and slash burning in short-rotation eucalypt plantations can promote negative changes in water quality (Lima 1993).

Perhaps the biggest water-related issue is the effect of eucalypts on soil water content. The uptake of soil water depends mainly upon the architecture of the root system of the trees and the way roots occupy the layers of the soil (Lima 1993). There are more than 600 eucalypt species, some with superficial root systems and others with deeper root systems (Jacobs 1955). Thus there are differences among these species in their capacity for water uptake. As in most natural forests and forest plantations, the roots of most eucalypt plantations are concentrated in the superficial layers of the soil (Reis et al. 1985); however, some eucalypt roots can grow to $30 \mathrm{~m}$ in depth (Jacobs 1955) and extract water from 6 to $15 \mathrm{~m}$ (Peck and Williamson 1987). The growth of the root system depends on environmental factors, mainly soil compaction (Nambiar 1981). Eucalypts seem to behave as any other tree plantation or natural forest cover with respect to the soil-water dynamics. They do not differ from other tree species with respect to the water balance of the watersheds. As with most timber harvesting there is an increase in soil water after harvest and 


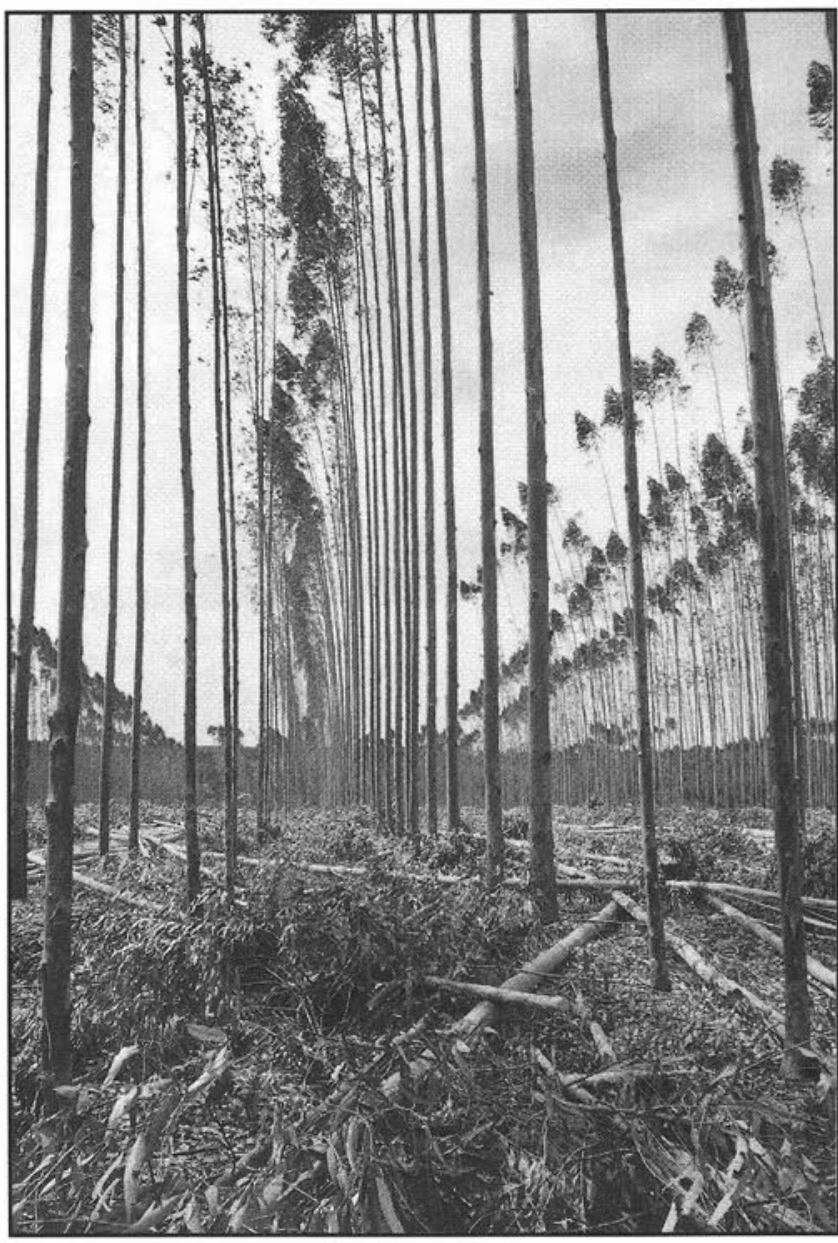

Figure 6. Harvesting 7-year-old eucalyptus plantation in Aracruz.

there will be a decrease when reforestation is complete (Lima 1993).

The effects of eucalypts on soil have been studied in several countries over many years. Most concerns deal with nutrient depletion or allelopathy caused by litter that is said to exert an antibiotic effect on soil microorganisms. Allelopathy was verified by research indicating a very low concentration of nitrifying bacteria in the litter of eucalypt plantations (Florenzano 1956). On the other hand, an extensive literature review demonstrated that reforestation with eucalypts improved soil fertility in the long term in several areas of the world (Karschon 1961). Reforestation has been recognized as one of the most effective means of reclaiming marginal, eroded or mined land (Van Goor 1985), but high growth rates and short-rotations, like those presented by most of the commercial eucalypt plantations, result in high nutrient uptake. In fact, in intensively managed eucalypt plantations, nutrient use can be comparable to that of an agricultural crop (Miller 1989), although agricultural crops normally require more total nutrients than the short-rotation eucalypt plantations (Lima 1993).

In a native forest ecosystem there exists a balance among the main components of the system as well as in the energy flows along the food webs. One of the most important factors responsible for the stability of the system is biodiversity (Evans 1992). Establishment of the monoculture short-rotation euca-

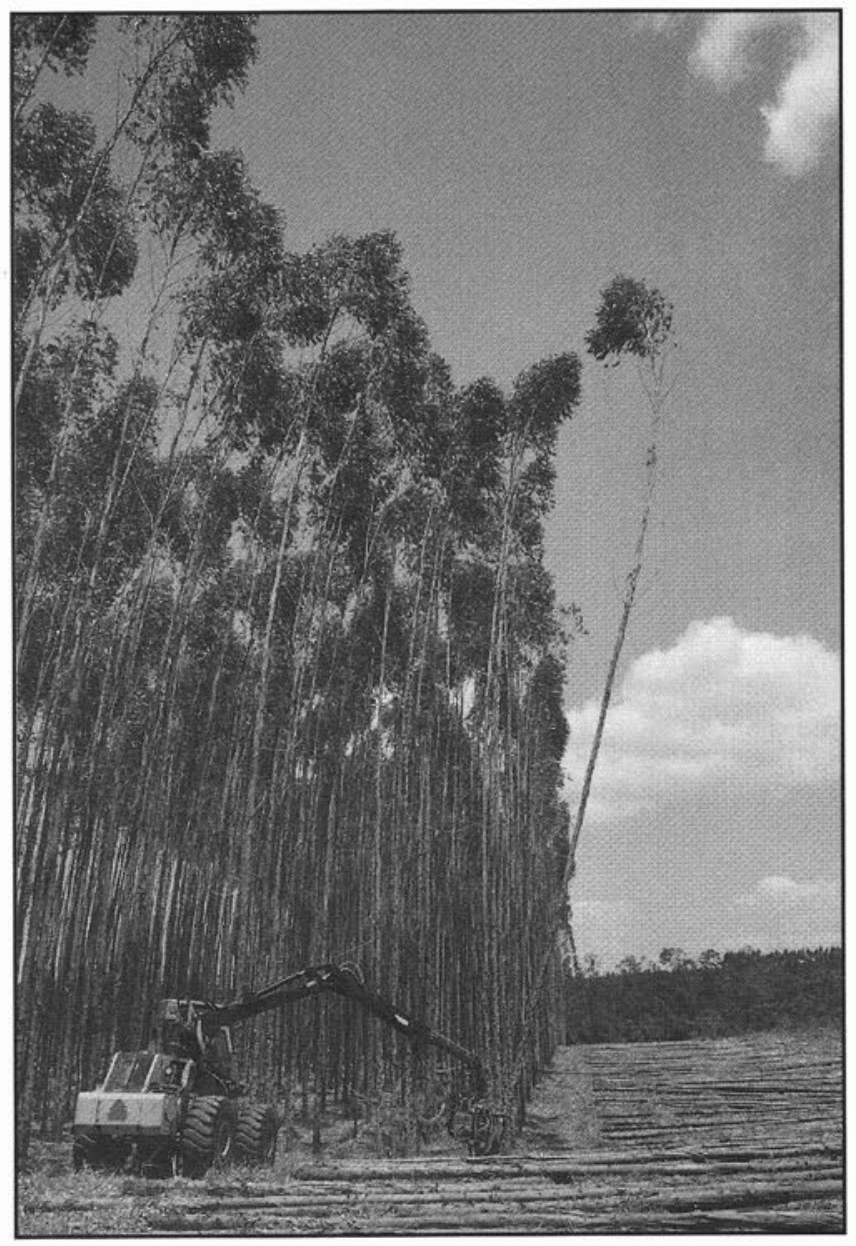

Figure 7. Harvesting 7-year-old eucalyptus plantation by a special harvester in Aracruz.

lypt plantations has been criticized as an activity that harms the environment by reducing the number of plant and animal species. These effects can be minimized, however, by adequate management of both the plantations and the remaining native forests and vegetation (Berndt 1992).

Since the beginning of the reforestation programs in the 1960s, forest industries have had two options when dealing with the preservation of the natural forests. They could either plant $1 \%$ of the total number of trees using only native species, or leave $10 \%$ of total area in the original vegetation (Reis and Reis 1993). The latter option was preferred because most of the reforested areas already had at least $10 \%$ of the area in riparian vegetation or forest cover, usually along the rivers and streams or on very steep slopes. These forests could not be harvested according to the National Forest Code. Furthermore, it was difficult to obtain seeds of native species in order to accomplish the planting option; because of this, regions where plantations are now established are typically composed of a mosaic of plantations, pastures, grasslands, croplands and native vegetation. This diversity of habitat creates a very important advantage in terms of wildlife preservation (Evans 1992).

Other company management practices obviously important to the success of a conservation program for fauna involve leaving native areas without planting (Moss 1979) or planting fruit trees and constructing small ponds throughout the plan- 


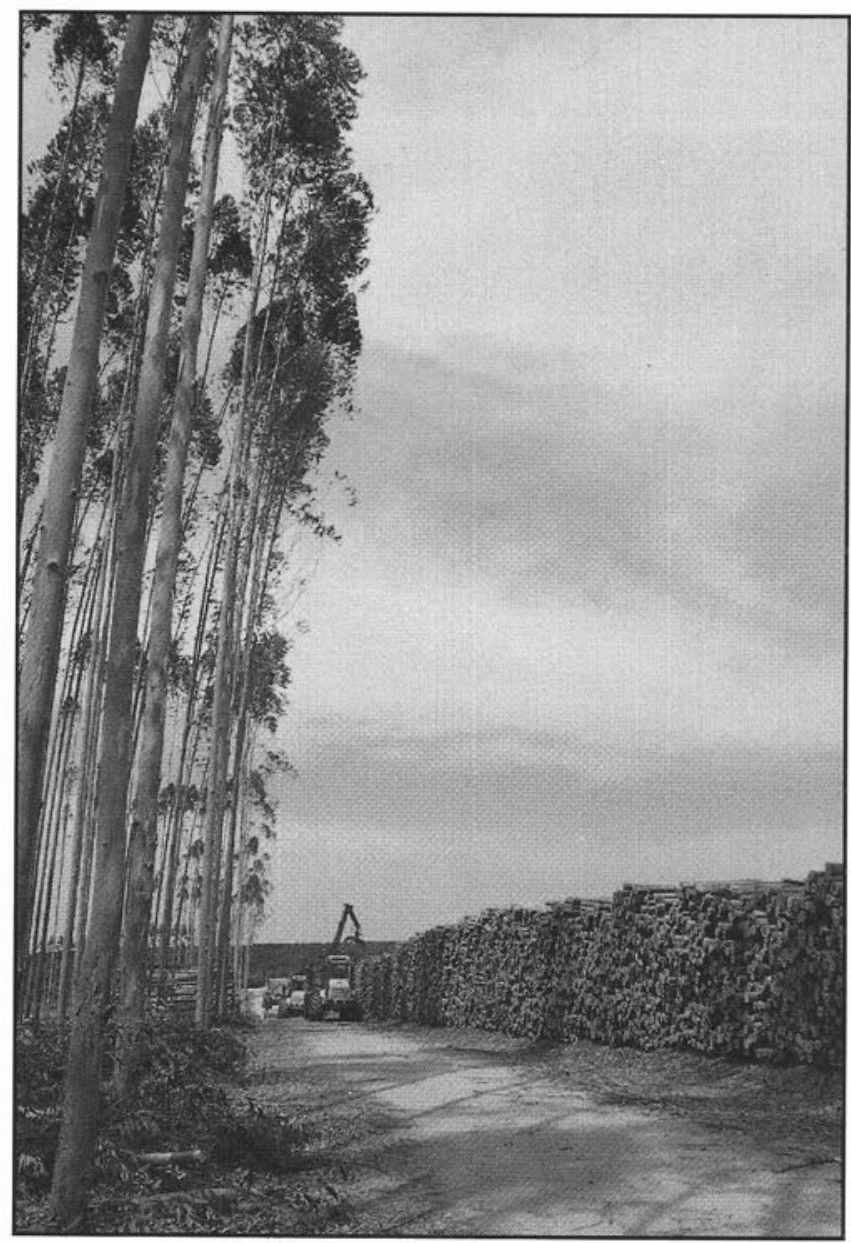

Figure 8. Piling of harvested eucalyptus timber in Aracruz.

tation area. These types of practices have been carried out recently by most forest companies in Brazil.

Critics of short-rotation commercial plantations assume that eucalypts have an allelopathic effect on other plants. This is expected to cause the disappearance of the original native plants and local ecosystems (Poore and Fries 1985). For the same reason, there is concern that agricultural crops cannot be cultivated on lands previously occupied by eucalypt plantations or even on nearby lands (Lima 1993). Some literature sources suggest that eucalypts can affect other plants directly through the inhibitory effects of leaf, litter and root exudates, or through the effect of litter on nutrient mineralization and the soil microflora (Florence 1986). On the other hand, a survey of the international literature reveals that direct plant-chemical interactions in natural communities are probably rare (Willis 1980). Regeneration of native species in the understory of eucalypt plantations is generally not restricted by the allelopathic effects of the litter (although a limited number of species can be affected). Regeneration is usually a function of the amount of sunlight reaching the ground under the eucalypt canopy, soil-water competition and, the existing seed supply of native species in the soil.

Newly planted seedlings are sensitive to weed competition during the first few months of stand establishment; therefore, it is common to use intensive silvicultural practices such as her- bicides, mechanized weeding and site preparation before planting. This allows the seedlings to grow free of weed competition at least during the earlier stages. These practices inhibit understory species, which do not normally reappear until the fourth year. At rotation age most of this understory vegetation is also eliminated to make it easier to harvest the eucalypts and to provide space for the new plantation or the sprouts of the eucalypt stumps. Thus, the occurrence of understory species can be reduced until rotation age in plantation areas (Reis and Reis 1993). However, if the eucalypt plantation is allowed to grow for longer periods of time, the original native species or ecosystems probably reestablish in the understory. Many observed effects of fast-growing eucalypt plantations might be attributed primarily to competition for soil nutrients and water during the rapid growth phase rather than any direct toxic influences the eucalypts may have on soils and other plants (Florence 1986).

Finally, when eucalypt plantations displace any existing ecosystem, the relative ecological and social importance of the existing ecosystems should be carefully balanced against the advantages to be gained from the new plantations (Palmberg 1986). Whether such replacement is justified can only be decided properly while considering the comprehensive national policy for the conservation of nature and genetic material (Poore and Fries 1985).

\section{Social Issues}

Short-rotation plantations may promote social benefits in the region where they are located (Beattie 1975). These direct and indirect social benefits were cited as: (i) job creation, (ii) income growth, (iii) flood control, (iv) erosion control, (v) watershed protection and water quality, (vi) recreation and leisure, and (vii) soil improvement. Under certain circumstances, forest plantations are considered better investments than other agricultural activities because of their low social cost (Capp Filho 1976). On the other hand, short-rotation plantations are also criticized as having social costs: (i) loss of water through evapotranspiration, (ii) soil nutrient depletion, (iii) runoff and sedimentation of rivers and streams, (iv) hazardous logging activities leading to high accident rates for employees, and (vi) damage to the road system (Worrel 1959). Obviously this is a controversial subject. One of the most easily measured benefits of plantations is the number of jobs generated and the salaries paid to employees. This has been used in most of the economic and social evaluation studies of the eucalypt plantations in Brazil (Neves 1979).

The forestry sector in Brazil is one of the best prospects for future development that contributes to the economic and social welfare of its increasing population (Siqueira 1990). Forestry activities offer job opportunities even in remote areas of the country. On average, each hectare of eucalypt plantation generates four directly related jobs. This indicates the economic and social importance of these plantations. In 1993 the forestry sector contributed US \$ 18.8 billion or 3.9\% of Brazil's Gross Domestic Project (Soresini 1993), and it is expected to increase its contribution to development in future.

In recent years, another positive social contribution of eucalypt plantations was their role in the disposal and recycling of residues such as urban waste and organic material. The risks of applying these residues to forest plantations are lower than those presented by similar systems in agricultural areas (Rizzi 
1993). The capacity of forest areas to renew and produce good quality water has been widely documented, but several factors must be considered in these forest systems: (i) the forest capacity to absorb a certain amount of waste water, (ii) the growth of the eucalypt species, (iii) impacts on fauna and flora, and (iv) contamination of streams and groundwater.

\section{Policy and Legislation}

Developing forestry activities requires the establishment of clear and well-defined legislation. National forest policy is employed by governments using legal and institutional means to develop the country's forestry sector. Despite the existence of a significant forest industry, it was not until the mid1950s that Brazilians began to establish a well-defined forest policy (Swioklo 1990).

The development of the country's forest sector follows the same pattern as its economic development, presenting region$\mathrm{al}$, social and sectorial differences that affect native and manmade forests as well as different wood-based products such as charcoal, firewood, pulpwood and timber. Despite the fact that Brazilian forest policy is based on fiscal incentives and shortrotation monoculture plantations of exotic species, native forests still make a large monetary contribution to Brazil's economy. In northern Brazil, native forests contribute $100 \%$ of the total harvest while in the southeastern region, short-rotation plantations contribute about $83 \%$ of the total (Ribas 1990).

Forestry activities were established in Brazil soon after it was discovered by the Portuguese in 1500 . These activities focused on the harvesting of brazilwood (Caesalpinia echinata). This was one of the main economic activitites in the early days of the country. With the development of agriculture and cattle raising, however, forestry activities were reduced to a less important role in the Brazilian economy. This situation existed until the 1960 s when the forestry sector started to receive more attention from the government.

From the beginning of Portuguese colonization there have been laws dealing with the protection of Brazil's native forests. These forests were considered the property of the Crown. Despite those laws, the Atlantic forest (along the Atlantic coast) was practically destroyed, either to provide timber and firewood or to provide land for agricultural activities. This situation led the government to establish laws in 1799 that regulated the harvesting of trees. There were severe penalties for those who did not follow the law. At that time, those individuals deliberately setting forest fires were punished with a capital sentence. Even with these severe penalties, deforestation of the Atlantic forest continued, leading Prince Dom João IV to enforce a new law requiring private land owners to preserve the forests located within a certain area of the Atlantic Coast and along certain rivers.

The first legislation supporting reforestation of the Atlantic forest was introduced in 1802 , and in 1813 the government made the cutting of brazilwood illegal. In 1825 the prohibition of cutting brazilwood was extended to other species but this did not reduce illegal cutting. At that time brazilwood was one of the main sources of income for the country's economy. In 1829 all cutting and burning on government forest lands had to be approved by a municipal government council. However, in 1831 circumstances changed completely. In that year all the laws concerning the harvesting and burning of trees and the Crown's monopoly of brazilwood and other species were removed. The rate of deforestation grew considerably and fire was used indiscriminately to clear the area for agricultural purposes (Swioklo 1990).

The first Brazilian Forestry Code was passed in 1934 (Decree 23793), but it was not enforced for about three decades, during which time deforestation occurred at an incredible rate (SBS 1987). In 1965, a new code was established to provide a new institutional model for forest legislation in the country. The 1960s were a time of key changes in forestry in Brazil for several reasons: (i) the new Brazilian Forestry Code, (ii) fiscal incentives for reforestation (iii) legislation for wildlife protection, and (iv) creation of the Brazilian Institute of Forestry Development (IBDF). The main objectives of the code were forest preservation, management and harvesting of the native forests, and replacement through reforestation programs of forests used by industries and the establishment of national forests devoted to multiple use (Ribas 1990).

Initially the Brazilian Forestry Code provided three types of fiscal incentives for native and planted forests; (i) the owners of any areas of planted or natural forest would not pay tax on them; (ii) income originating from natural forests or plantations would not be subjected to taxation; (iii) funds used for afforestation or reforestation would be deductible from the income tax of individual owners and companies. In 1966, Law 5106/66 established the rules for the tax incentives for reforestation, setting a 50\% limit on the deduction of these expenses from total income. One problem arising from Law 5106/66 was that taxpayers had to incur expenses before declaring their deduction from income tax. In 1970, Law $1134 / 70$ provided that the companies and individuals could use up to $50 \%$ of projected income tax to apply to new forest investments. From 1965 to 1974 , therefore, there were Laws (5106/66 and 1134/70) that provided fiscal incentives for reforestation in Brazil.

The 1970 Law (1134/70) promoted a boom in the forest sector of the country when several industries specializing in reforestation emerged. But some problems appeared as a result of this new law. Most of the industries would receive a percentage of their taxes back but would not follow up with implementing reforestation projects. This situation prevailed until 1974 when Law 1376/74 tried to correct the distortions of Law $1134 / 70$. This new law created the Fiscal Incentives Fund requiring companies to submit their money to that fund and not to a specific reforestation project planned by a particular forest company. In 1983, Law 88207 established new regulations to govern fiscal incentives for reforestation purposes. These new regulations required companies to commit project money 6 months in advance of asking for rebates on their taxes. This resulted in a very strong negative reaction on the part of forest industries. The Brazilian Association of Forest Companies claimed the new legislation would bankrupt the emerging forest sector and cause umemployment.

In 1986 new legislation promoted additional changes in the fiscal incentives rules for reforestation, leading once again to a strong negative reaction from forest companies. In 1987, Law $1297 / 87$ was passed, which limited tax-deduction application for reforestation to $10 \%$ and confined it to only certain areas in the states of Minas Gerais and Espírito Santo. Finally, in 1988 the fiscal incentives for reforestation were discontinued by Law $7714 / 88$, thus ending a very important chapter of the development of the forestry sector in Brazil. In 1989, IBDF was terminated by the government. In its place IBAMA, the Brazilian 
Institute of Environment and Natural Resources (IBAMA) was created.

In 1993 the Federal Constitution of Brazil provided new guidelines for forest legislation. Today, not only the federal but also state and municipal governments can pass legislation dealing with forestry. The preservation of forests, fauna and flora has become a common obligation of federal, state and muncipal governments (Swioklo 1990).

\section{Forest Industries}

Brazil's primary wood-using industries include charcoal-based cement, iron and steel-making companies, pulp and paper mills, composite board plants, veneer and plywood mills, wood preservation plants, and sawmills. Important secondary forest industries produce furniture, windows, doors, wooden houses, pallets and other products. Charcoal-based cement, iron and steel-making companies, and pulp and paper and composite board industries, which are described in more detail below are by far the most commercially important to the Brazilian economy.

\section{Cement, Iron and Steel}

Brazil's reserves of oil and coal are relatively small when compared to the extent of its territory, which amounts to about $50 \%$ of South America. Brazilian coal is also of low quality for producing iron and steel because its high sulfur and ash content. In Brazil, therefore, unlike most industrialized countries, charcoal has played a very important role in the development of the iron and steel production sector. The use of wood has placed a heavy burden on native forests and has contributed to the development of the large-scale short-rotation plantation forestry over the last 25 years. In 1989 the charcoal-based cement, iron and steel industries consumed 35 to 40 million $\mathrm{m}^{3}$ of wood, from which only 6 to 7 million $\mathrm{m}^{3}$ came from eucalypt plantations. In 1991 the charcoal-based cement iron and steel industries contributed US $\$ 3$ billion to the country's economy, generating 189,500 jobs and paying US $\$ 485$ million in taxes revenues (ABRACAVE 1992).

Approximately 10 years ago native forests accounted for $80 \%$ of the total supply of charcoal, and forest plantations only $20 \%$. By 1991 the contribution of native forests to charcoal production decreased to $60 \%$ of the total with forest plantations rising to $40 \%$. Using 1982 as the basis for comparison, utilization of native forest-based charcoal increased by about $120 \%$ while forest plantation-based charcoal utilization increased by about $350 \%$. This is a positive trend from both environmental and economic points of view. Now that the government has removed some fiscal incentives from the forest sector, several charcoal-based industries will switch to imported metallurgical coal and this will help to alleviate the pressure on native forests. The government program called "Our Nature" was created in 1989 to generate $100 \%$ self sufficiency in the charcoal-based industries within a 7 year period. In the Amazonia region this goal would be attained by sustained yield management of the native forests, while in the other parts of the country it would be accomplished through plantation forestry.

The firewood and charcoal-based energy framework was economically viable while subsidies existed. Today some very important iron and steel-making companies such as ACESITA and BELGO MINEIRA are substituting imported metallurgical coal for charcoal and selling their forest plantations to pulp and paper industries that supply domestic and international markets.
Some joint ventures planned by former wood-for-biomass energy producers and national and international pulp and paper groups are under study and development.

On the other hand, some iron and steel-making industries such as MANNESMANN and PAINS are still using charcoal from their forest plantations to supply their plants. These industries are developing new technologies, however, to convert wood into charcoal more efficiently and also obtain by-products such as tar, chemicals and electricity from the carbonization process. It is clear that charcoal as an energy source in Brazil will only survive if new technologies make its production a viable economic activitiy.

\section{Pulp and Paper}

There are about 30 pulp and paper mills in Brazil today and five additional ones are under construction. The largest mills with the most advanced technology are CHAMPION, SUZANO, RIPASA, and CELPAV in São Paulo, CENIBRA in Minas Gerais, RIOCELL in Rio Grande do Sul, MANVILLE, PCC and RIGESA in Santa Catarina, KLABIN, PISA and INPACEL in Paraná, ARACRUZ in Espírito Santo, BAHIA-SUL in Bahia and JARI in Pará.

JARI, a pulp company located in the Amazonian region, produces 300,000 tons of bleached kraft pulp annually ( $45 \%$ short-fiber and 55\% long-fiber). The company has about 3,100 full-time employees and needs 1.55 million tons $\mathrm{yr}^{-1}$ of wood harvested from its short-rotation plantations of eucalypts $(32,900 \mathrm{ha})$, gmelina $(8,300 \mathrm{ha})$ and pines $(41,200 \mathrm{ha})$. In 1992 and 1993, the company planted 24,000 ha and the 1994 planting program is estimated to be $18,000 \mathrm{ha}$. JARI is a sustainable development model in the Amazon, proving that any region can be productive and prosperous if the resources are used rationally.

CHAMPION, was considered in 1993 to be the best pulp and paper industries in Brazil (based on growth, profitability, liquidity, productivity and capitalization). The company produces 800 tons of pulp and 900 tons day $^{-1}$ of paper. It consumes 1.8 million $\mathrm{m}^{3}$ of wood for pulp and 0.47 million $\mathrm{m}^{3}$ of fuelwood for energy, obtained from its 62,700 ha of short-rotation eucalypt plantations in São Paulo and Mato Grosso do Sul. The company plants 4,000 ha annually and is $82 \%$ self-sufficient in wood supply.

ARACRUZ, the biggest eucalypt-based pulp mill in the world, produces more than 1 million metric tons of kraft pulp annually. The company has always met $100 \%$ of its pulp needs by using its own managed eucalypt forests or by purchasing eucalypts from local growers without including any native trees. For every 2.4 ha of eucalypt plantation, the company preserves 1 ha of forest with native species. ARACRUZ employs 7,000 workers, $60 \%$ of whom are natives of the state of Espírito Santo, with the remaining $40 \%$ from the neighbouring states of Minas Gerais and Bahia.

PISA, the main Brazilian newsprint producer (150,000 tons annually) is self-sufficient in wood production for its industrial plant. The company has 73,000 ha of short-rotation eucalypt $(4.1 \%)$, pines $(92.3 \%)$ and other species $(3.6 \%)$ and has an annual planting program of 2,500 ha. Ecological compatibility of tree species with their sites is a priority at PISA. More than $40 \%$ of the company's total land is occupied by native vegetation.

In 1991 the pulp and paper sector alone used 4.3 million $\mathrm{m}^{3}$ of wood for energy as a substitute for fuel oil. Of this total, 
Eucalyptus species accounted for $61.5 \%$ and Pinus for $19.6 \%$ and $18.9 \%$ came from other forest species. To supply their needs in this fuel oil-for-biomass substitution and to produce pulp and paper, the pulp and paper sector has established 1.4 million ha of forest plantations and is planning to establish an additional 855000 ha of plantation by the year 2000 .

\section{Composite Boards}

Seven major particle and hardboard plants are located throughout Brazil and operated by the DURATEX and EUCATEX corporations, both Brazilian-owned. DURATEX, with its headquarters in São Paulo, has a 70\% market share of these products. It has four particle board plants in the state of São Paulo, one plant in Bahia, and one in Rio Grande do Sul. In 1990 DURATEX processed 2 million $\mathrm{m}^{3}$ of logs, from which it produced $350,000 \mathrm{~m}^{3}$ of particle board. The other major corporation, EUCATEX, also located in the state of São Paulo, manufactures mostly hardboard, and has a Brazilian market share of about $30 \%$.

\section{Forestry Education}

Forestry education in Brazil began in 1960 when the National School of Forestry was established at Viçosa, Minas Gerais, by the federal government under the auspices of the Food and Agriculture Organization of the United Nations (FAO). In 1964 the National School of Forestry was transferred to Curitiba, Paraná and a new school was established by the state government in Viçosa. Fourteen years later a graduate program was initiated at that school, now called the Department of Forestry of the Federal University of Viçosa (Reis and Reis 1993).

In 1977 an agreement was signed between the Brazilian and Canadian governments to enhance the quality of the undergraduate and graduate forestry programs at the Federal University of Viçosa. This agreement, which lasted about 7 years, involved the training up to doctorate level of several professors from Viçosa at the University of Toronto and the University of British Columbia under the auspices of the Canadian International Development Agency (CIDA). The Federal University of Viçosa also received computers and other equipment as well as the assistance of Dr. Ronald R. Ayling as a Visiting Professor from the University of Toronto. As a consequence of that assistance from Canada, the undergraduate and graduate courses of the Federal University of Viçosa have ranked first in Brazil and in Latin America in the last 10 years. In 1994 there is an ongoing agreement between the Université Laval and the Federal University located at Lavras, in Minas Gerais, to improve that university's undergraduate forestry program.

Today there are about fifteen forestry schools in Brazil. They are spread throughout the country in cities like Manaus and Belém in the north, Patos and Recife in the northeast, Brasilia and Cuiabá in centralwest, Viçosa, Rio de Janeiro, Lavras, Piracicaba and Botucatu in the southeast, and Curitiba and Santa Maria in the south.

Among these, the school located at Viçosa has the strongest program oriented towards eucalypt plantations and utilization. This is because the state of Minas Gerais is the leader in short-rotation eucalypt plantations established in Brazil. The Department of Forestry of the Federal University of Viçosa pioneered the introduction of the use of microcomputers and geographic information systems as tools for forest planning. It was also the first forestry school to introduce the formal teach- ing of agroforestry at graduate level, becoming the national leader in eucalypt-based agroforestry research.

The school located at Piracicaba in the state of São Paulo also has a very strong eucalypt-oriented forestry program. Since most of the forest industries that use eucalyptus wood as raw material are located in the southeastern region of the country, it is logical that the strongest eucalypt-oriented forestry education programs be located there. The schools located in Curitiba and Santa Maria have a stronger pine-oriented program, while those located in the other regions have their program oriented more towards local species and forest vegetation.

In 1967 the University of São Paulo signed an agreement with some forest industries to create the Institute for Forest Research (IPEF). Since most of the industries associated with this institute used eucalypt wood as raw material, they had a strong influence on the research program as well on the graduate and undergraduate forestry programs at Piracicaba. A similar situation occurred in 1974 when the Federal University of Viçosa signed an agreement with several forest industries in Minas Gerais and Espírito Santo, creating the Society for Forest Research (SIF). All these industries used eucalypt, either for charcoal or pulp. Their influence on the research program and on the graduate and undergraduate forestry programs of the Federal University of Viçosa has been considerable. Over the last 10 years this university has offered some of the best undergraduate and graduate forestry courses in Brazil and Latin America.

In these universities during the 1970s and 1980s, most courses and research focused on silviculture, forest management, tree breeding and improvement, fertilization, forest protection and wood technology (the production of charcoal, pulp and paper, particle boards and essential oils). In the late 1980 s and now in the early 1990 s, the objective is sustainable development. Thus, subjects such as forest planning, agroforestry, harvesting mechanization, nutrient cycling, genetic improvement (clones, hybrids), biological control of pests and diseases, forest legislation and policy, environmental and social impacts of forest plantations, soil conservation watershed management, biodiversity conservation, and urban forestry have become very important. Both the graduate and undergraduate programs of the schools of forestry in most of the Brazilian universities have been modified to fit the current needs of the private and government institutions as well as society as a whole. About 4,600 foresters have graduated since 1965 from 15 universities; of these, $60 \%$ are working for the private sector (Siqueira 1990).

\section{Forest Research}

In the late 1960s, forest research was one of the tasks of IBDF (now IBAMA; IBDF). The research effort tried to address immediate problems or to attend to the most prominent needs of the forest companies and other forest organizations such as SIF and IPEF. Most of the forest research is done by EMBRAPA (Brazilian Enterprise for Research in Agriculture) through its research centers and by universities, forest companies and state research institutions. The national government created EMBRAPA in 1972 to coordinate and conduct all the agricultural and forestry research (instead of IBAMA) in the country. Today EMBRAPA has a network of 40 research centers throughout the country. Significant among them are the agroforestry centers located in the Amazonia region (Manaus, Acre, Rondônia and Belém), the centers located in the semi- 
arid (Petrolina) and savanna (Brasilia) regions, and the National Center for Forestry Research (CNPF) located in Curitiba in the south (Hoeflich 1993). Despite the considerable number of institutions devoted to forest research, there is a lack of coordination among them which sometimes leads to inefficiency and dispersion of funds, labor and equipment (Siqueira 1990).

In the 1960s little if anything was known about the silvicultural and ecological needs of introduced eucalypt species. They were planted throughout the country on different soil types and in various climatic conditions. Availability of land and low prices were the factors considered in most of the reforestation projects. There was no ecological zoning or use of certified seeds with the correct provenance to ensure the success of plantations. Eucalyptus grandis, which was the most popular and fastest growing species, was used indiscriminately by most of the companies; this resulted in low survival rates for some plantations.

Because no provenance tests were established in the country, the same species would grow well in one place and not in another. Annual wood productivity was low in some areas, ranging from 6 to $12 \mathrm{~m}^{3}$. In other regions the same species would produce 25 to $30 \mathrm{~m}^{3}$ annually. Coppicing was not occurring as expected, and even when successful, the second rotation would not yield as much as the first. Often, yields would decrease by 20 to $40 \%$ from one rotation to another. In the early 1960 s there were also intensive attacks of insects and fungi, mainly on Eucalyptus grandis plantations. There were no adequate site preparation technologies. Fire was used to help eliminate the original vegetation in most areas. Soil preparation was similar to the system used for agricultural crops which sometimes led to erosion and silting of streams. No attention was given to any physical or chemical impediment in the soil layers that could jeopardize the growth of the newly established plantations. There were no adequate fertilization formulas or methods of application. Even spacings and rotation lengths were unknown at that time.

In the 1970s the situation changed drastically with the implementation of ecological zoning for reforestation with eucalypts and pines based on work done by Lamberto Golfari (1975), an expert from FAO. A network of species and provenance trials throughout the country was established with the help of EMBRAPA. Golfari used Thorntwaite's water balance to compare the regions of eucalypt species and provenance origin with the different regions in Brazil where these species would be introduced. Now Golfari's ecological zoning for reforestation is being improved and refined by EMBRAPA and by the Department of Forestry of the Federal University of Viçosa. This new technology is incorporating climatic (Martins et al. 1992), ecological, and edaphic variables (Tristão 1992) into the ecological zoning, using a multivariate analysis technique (Reis and Reis 1993).

With ecological zoning and the introduction of new species and provenances tested by EMBRAPA and the forest companies (allied with better silvicultural and management practices) there was a significant improvement in the productivity levels of the plantations during the $1980 \mathrm{~s}$. The average growth was around 18 to $22 \mathrm{~m}^{3} \mathrm{ha}^{-1}$ annually, with some hybrids and clones producing almost double that. In 1994, average annual productivity is around $35 \mathrm{~m}^{3} \mathrm{ha}^{-1}$ but in some places plantations can grow at the incredible rate of 90 to $100 \mathrm{~m}^{3} \mathrm{ha}^{-1}$ annually (Reis and Reis 1993).

\section{Future Trends}

\section{Agroforestry}

In the 1970s the increasing price of land surrounding company facilities in southeastern Brazil stimulated forest companies as well as state governments to begin local forest farmer programs to reinforce wood supplies. These programs, however, were denounced by local farmers because they felt eucalypt plantations would divert land from food to timber production (Assis et al. 1986). There was a widespread belief that the forest farmer programs would result in decreased food crop production.

Given this situation, agroforestry appeared to be an alternative that could integrate both timber and food production on the same site, meeting food demands while addressing timber needs. In order for agroforestry to be acceptable, however, it was necessary for both companies and farmers to have accurate biological, technical and economic information about the intercropping of agricultural crops and tree plantation species. In southeastern Brazil the most important forest plantation species and agricultural crops are eucalypts, pines, rubber trees, corn, beans, rice, coffee, soybeans and sugar cane.

Agroforestry as a science is relatively new despite being an historical land use in Brazil as well as other parts of the world. Agroforestry research in Brazil, particularly involving eucalypts, is relatively new. By 1986 the relevant literature for agroforestry with eucalypts in southeastern Brazil consisted of only three studies: Eucalyptus alba intercropped with corn in the state of São Paulo (Gurgel Filho 1962); Eucalyptus grandis intercropped with soybeans in Minas Gerais (Couto et al. 1982); and Eucalyptus grandis with beans in São Paulo (Schreiner and Balloni 1986).

The success of these studies induced researchers from the Federal University of Viçosa to continue studying a series of eucalypt agroforestry systems. These studies were a joint research effort of forest industries in the state of Minas Gerais and the university. They were funded by the SIF and the forest companies. This research included Eucalyptus torelliana intercropped with com in Belo Oriente (Moniz 1987), Eucalyptus grandis with black beans in Peçanha (Passos 1989), Eucalyptus citriodora with Panicum maximum in a silvopastoral system with cattle and sheep in Dionísio (Almeida 1990), Eucalyptus cloëziana with herbaceous legumes and grasses for cattle grazing in Montes Claros (Santos 1990), and, most recently, Eucalyptus grandis intercropped with herbaceous legumes for weed suppression and soil protection in Dionísio (Ferreira Neto 1993). In 1994 most of the forest companies in Brazil are adopting agroforestry as an alternative land use, mainly for their forest farmer programs.

\section{Wood Biomass Gasification}

Studies conducted by Brazilian industries have shown that energy production from biomass cannot compete in price with energy generated from oil, coal and natural gas. The only way it can compete is by generating a more valuable form of energy viz electricity. This is possible by using the Biomass Integrated Gasification/Gas Turbine (BIG/GT) developed in the U.S.A. with the participation of Princeton University. In this technology, the biomass is gasified and the gas is used to move a turbine that produces electricity. The exhaust gases from the turbine are captured for additional energy production. Compared to the traditional 20\% efficiency of steam-based elec- 
tricity production systems, this new technology has a $40 \%$ conversion efficiency. In 1992 Brazil submitted a technical proposal to the Global Environmental Facility (GEF) to build an experimental BIG/GT-run plant and to study the economic feasibility of the process. The project, composed of five stages, was approved and is now underway.

The first stage of the project was to evaluate the technical proposal and preinvestments studies. The second stage, to be concluded in 1994, is in progress and involves the development of equipment, basic engineering, economic feasibility studies and preparation of the basic structure for the next stage. The third stage will consist of the construction of an operational plant, in a 24 - to 30 -month period, using US $\$ 23$ million funded by GEF. Additional capital resources will be provided by the associated companies: ELETROBRAS, CHESF, CIENTEC, CVRD, SHELL BRAZIL S.A. and SHELL INTERNATIONAL PETROLEUM COMPANY. This joint venture is coordinated by the Ministry of Science and Technology, and the experimental facility will be built in Bahia close to eucalypt plantations. The fourth stage will be 24 months in duration and will comprise operational demonstration tests with sugar cane bagasse and wood biomass. And finally, the fifth stage will be the commercial operation of the plant as an industry.

This BIG/GT project in Brazil is the first of its kind in the world. If successful it will bring many advantages: decentralization of electrical energy production; reduction of energy transmission costs; small capital investments allowing private companies to enter the sector; use of marginal agricultural lands for short-rotation plantations devoted to biomass for electricity energy production; generation of rural jobs; and increased utilization of the Brazilian wood energy potential. The northeastern region of Brazil alone has an annual potential of 197.1 million $\mathrm{m}^{3}$ of wood and 19,673 thousand megawatts of energy annually.

\section{SEIVAS}

In 1992 the Brazilian Forestry Society (SBS) along with private forest companies proposed the creation of SEIVAS, a US $\$ 500,000$ Integrated Management System for the Valorization of Forestry Affairs. This system is designed to project the world environment 10 to 20 years in the future, and enable the establishment of goals for the Brazilian forestry-based products in the international market. Based on world market trends and local conditions, the system will ultimately identify markets in which Brazil will enjoy a greater competitive edge. Furthermore, the system will indicate what areas need to be developed to reach these goals. Two parts of the system are already being implemented: (i) the program for preservation and recovery of the Brazilian forest cover, (ii) and the CERFLOR project related to the origin of the raw material utilized in manufacturing of forestry products. A certificate called "Green stamp" will be issued for any forest raw material or product originating from native forests or plantations managed according to environmentally sound techniques. Coordination and implementation of the rules for assignment of this certificate is the responsibility of EMBRAPA, and the project will be assessed by several universities and scientific organizations in the country (Boratto 1993).

\section{FLORAM}

FLORAM is a social forestry project proposed in 1990 by the Institute of Advanced Studies of the University of São Paulo with the objective of establishing 20 million ha of forest plan- tations in Brazil in the next 20 years. This project, according to the Industrial Institute for Economic and Social Research at Stockholm, Sweden, would generate one million jobs and would produce US $\$ 10$ billion annually in forest products. This project has received the support of the private sector, universities, research institutions and non-governmental organizations and is now underway (Coelho 1993). In the Floram project three types of forests were proposed: the first for industrial purposes, using exotic tree species, the second for dual purposes (conservation and commercial utilization), using exotic and native tree species, and the third for conservation only, using native tree species.

\section{Conclusions}

The Brazilian forestry sector has, in its short history, made remarkable progress. Government forestry services are well-organized and use up-to-date domestic and international research results to improve forest management and protection and to enhance the competitiveness of their industries. These industries have sufficient Brazilian and foreign capital to acquire the most modern technology and employ competent professionals. Forestry education facilities are available to serve the needs of forest researchers, government services and the forest industry and with assistance from countries such as Canada, these facilities are rapidly improving. Problems have arisen from a scarcity of trained workers and good machinery, but these problems are counterbalanced by favorable climate, rapid plantation growth, short rotations, and a competitive forest industry.

In 1994, environmental groups are exerting considerable pressure on public opinion to make it difficult for the establishment of short-rotation monoculture forest plantations (mainly eucalypts). These groups have played a very important role in affecting the decisions made by the forest industry about the environmental effects of short-rotation plantations. Timber production forestry has to give way to sustainable forestry for multiple use, in which water, air quality, erosion control, wildlife, recreation and landscape are considered as valuable as timber production. Integrated forest management requires an understanding of the relationships among the various components of the forest ecosystem so that management practices are implemented to minimize the environmental impacts of plantations. To do that one must take into account: (i) hydrologic and ecological aspects, (ii) capacity of the soil to produce on a sustainable basis, (iii) biodiversity of the area, and (iv) preservation of species habitats.

The forestry sector in Brazil will participate in a growing worldwide trend to balance the economic and social needs for the improvement of the quality of life of the population. Pressure has been exerted on Brazil by the international community to practise sustainable forestry. Organizations such as the World Bank and the Inter-American Development Bank are linking loans to the obligation of the recipient country to promote the environmental assessment of development projects for which they are seeking funds. Some European countries are boycotting forest products imported from tropical countries if they originate from unmanaged forests or from forest industries that do not comply with high environmental standards.

\section{Acknowledgements}

The authors wish to thank the owners and management personnel of the forest industries of Brazil for their assis- 
tance, especially Dr. N. Nicolielo and Dr. A.J. de Oliveira of DURATEX S.A., Agudos, São Paulo. Thanks are also due to M. Mason of Canadian Forest Service, Edmonton, Alberta, Canada, and to Dr. R.D. Laven of the Department of Forest Sciences, Colorado State University, Fort Collins, Colorado, U.S.A. for providing editorial assistance.

\section{References}

Abracave. 1992. Anuário Estatístico 1992. Associação Brasileira de Carvão Vegetal. Belo Horizonte. 11 p.

Almeida, J.C.C. 1990. Comportamento inicial do Eucalyptus citriodora Hooker, em áreas submetidas ao pastejo com bovinos e ovinos no Vale do Rio Doce, Minas Gerais. Universidade Federal de Viçosa, Imprensa Universitária, $44 \mathrm{p}$.

Assis, J.B., E. Silva and J.C.A. Araujo. 1986. Desempenho do reflorestamento em pequenos e médios imóveis na Zona da Mata. Silvicultura 41: 50-55.

Ayling, R.D. and P.J. Martins. 1981. The growing of eucalypts on short-rotation in Brazil. For. Chron. 57(1): 9-16.

Beattie, W.D. 1975. An economic analysis of the Brazilian fiscal incentives for reforestation. (Ph.D. thesis). Purdue University, West Lafayette. 301 p.

Berndt, R.A. 1992. Influência da estrutura da vegetação sôbre a avifauna em uma floresta alterada de Araucaria angustifolia e em reflorestamentos, em Telêmaco Borba, Paraná. Piracicaba 221. (M.S. thesis).

Betters, D.R., L.L. Wright and L. Couto. 1991. Short rotation woody crop plantations in Brazil and the United States. Biomass and Bioenergy 1(6): 305-316.

Boratto, J.H.T. 1993. É hora de união. Silvicultura (50): 8-12.

Borg, H., A. Hordacre and F. Batini. 1988. Effects of logging in stream and river buffer on watercourses and water quality in the southern forest of Western Australia. Aust. For. 51(2): 98-105.

Capp Filho, M. 1976. Avaliação econômica do reflorestamento no estado de Minas Gerais: efeitos do Incentivo Fiscal. (M.S. thesis). Viçosa, UFV, Imprensa Universitária 107 p.

Charley, J.L. and B.N. Richards. 1983. Nutrient allocation in plant communities. Mineral cycling in terrestrial ecosystems: physiological plant ecology IV. Springer-Verlag. pp. 6-45.

Coelho, M.A. 1993. O FLORAM como modelo. Estudos Avançados (31): 2 .

Coufal, J.E. 1989. Forestry: in evolution or revolution? J. For. May: 27-32.

Couto, L., N.F. Barros and G.C. Rezende. 1982. Interplanting soybean with eucalypt as a 2-tier agroforestry venture in southeastern Brazil. Aust. For. Res. 12: 329-32.

Duerr, W.A. 1990. Forestry as a system. J. For. April: 19-22.

Evans, J. 1992. Plantation forestry in the tropics. Clarendon Press Oxford. Second edition. 403 p.

Ferreira Neto, P.S. 1993. Comportamento inicial do Eucalyptus grandis W Hill ex Maiden em plantio consorciado com leguminosas na região do médio rio Doce, Minas Gerais. Universidade Federal de Viçosa, Imprensa Universitária. 83 p.

Florence, R.G. 1986. Cultural problems of eucalyptus as exotics. Commonw. For. Rev. 65(2): 141-163.

Florenzano, G. 1956. Ricerche sui terreni coltivati ad eucalitti. Il ricerche microbiologiche e biochimiche. Publicazione del Centro di Sperimentazione Agricola e Forestale 1: 133-152.

Gash, J.H.C. 1979. An analytical model of rainfall interception by forests. Q.J.R. Meteorol. Soc. 105: 43-55.

Golfari, L. 1975. Zoneamento ecológico do Estado de Minas Gerais para reflorestamento. PRODEPEF. PNUD/FAO/IBDF/BRA-71545 , Série Técnica $\mathrm{n}^{\circ} 3.65 \mathrm{p}$.

Gurgel Filho, O.A. 1962. Plantio do eucalipto consorciado com milho. Silvicultura em São Paulo, 1(1): 85-102.

Hatch, A.B. 1976. Some chemical properties of forest stream water in Western Australia. Bull. 89, Perth, For. Dep. 27 p.
Hoeflich, V.A. 1993. Priorização de demandas de pesquisa na EMBRAPA - Empresa Brasileira de Pesquisa Agropecuária. Anais do I Simpósio Brasileiro de Pesquisa Florestal. SIF 319-328.

Jacobs, M.R. 1955. Growth habits of the eucalypts. Forest and Timber Bureau, Commonwealth of Australia, Canberra. 262 p.

Karschon, R. 1961. Soil evolution as affected by eucalyptus. Segunda Conferência Mundial do Eucalipto. São Paulo. FAO, Relatórios e Documentos 2: 897-904.

Lima, W.P. 1961. Impacto ambiental do eucalipto. Editora da Universidade de São Paulo, São Paulo. Second edition. 301 p.

Magalhães Neto, J.L. 1993. Futuro do carvão vegetal no contexto nacional e no exterior. Anais do I Simpósio Brasileiro de Pesquisa Florestal. SIF 240-249.

Martins, S.V., M.G.F. Reis, A.L. Souza, C. Aspiazu and G.G. Reis. 1992. Classificação ecológica do Estado do Espírito Santo Baseada em condições climáticas. Revista Árvore 16: 272-296.

Miller, H.G. 1989. Internal and external cycling of nutrients in forest stands. Biomass production of fast-growing trees. Kluwer Academic Publishers. pp. 73-80.

Moniz, C.V. 1987. Comportamento inicial do eucalipto (Eucalyptus torelliana F Muell), com milho (Zea mays L) no Vale do Rio Doce, em Minas Gerais. (M.S. thesis). Viçosa, UFV, Imprensa Universitária. $61 \mathrm{p}$.

Moss, D. 1979. Even-Aged plantations as a habitat for birds. Ecology of even-aged forest plantation. Institute of Terrestrial Ecology, Reino Unido. pp. 413-427.

Nambiar, E.K.S. 1981. Ecological and physiological aspects of the development of roots: from nursery to forest. Australian Forest Nutrition Workshop, CSIRO, Melbourne, pp. 117-129.

Neves, A.R. 1979. Avaliação sócio-econômica do um programa de reflorestamento na região de Carbonita, Vale de Jequitinhonha, MG. (M.S. thesis). Viçosa, UFV, Imprensa Universitária. 72 p.

Palmberg, C. 1986. Are eucalypts ecologically harmful?Unasylva, 38(152): 19-28.

Passos, C.A.M. 1989. Comportamento inicial do eucalipto (Eucalyptus grandis W Hill ex Maiden) em plantio consorciado com feijão (Phaseolus vulgaris L), no Vale do Rio Doce, Minas Gerais. (M.S. thesis) Viçosa, UFV, Imprensa Universitária. 64 p.

Peck, A.J. and D.R. Williamson. 1987. Effects of forest clearing on groundwater. J. Hydrol., 94: 47-65.

Poore, M.E.D. and C. Fries. 1985. The ecological effects of eucalyptus. FAO For. Pap. 59.87 p.

Reis, M.G.F., J.P. Kimmins, G.C. Rezende and N.F. Barros. 1985. Acúmulo de Biomassa em uma Sequência de Idade de $E$. grandis Plantado no Cerrado em Duas Áreas com Diferentes Produtividades. Revista Árvore, 9: 149-162.

Reis, M.G.F. and G.G. Reis. 1993. A contribuição da pesquisa florestal para a redução de impactos ambientais do eucalipto. Anais do I Simpósio Brasileiro de Pesquisa Florestal. SIF 119-135.

Ribas, L.C. 1990. A economia, a legislacao e a politica florestal Brasileiras. Anais do $6^{\circ}$ Congresso Florestal Brasileiro, Campos do Jordão. SBS (1): $179-185$.

Rizzi, N.E. 1993. Aplicação de agua residual urbana em sedimentos de solo florestal argiloso: estudo experimental. Anais do $7^{\circ}$ Congresso Florestal Brasileiro (1): 15-19.

Sampaio, A.N. 1975. O eucalipto e a ecologia. Boletim técnico, Aracruz Celulose S.A. pp. 5-14.

Santos, F.L.C. 1990. Comportamento do Eucalyptus cloëziana F Muell em plantio consorciado com forrageiras, na região do cerrado, em Montes Claros, Minas Gerais. (M.S. thesis). Viçosa, UFV, Imprensa Universitária. $83 \mathrm{p}$.

SBS 1987. A conservação da natureza e o patrimônio florestal Brasileiro. Sociedade Brasileira de Silvicultura. 14 p.

Schreiner, H.G. and E.A. Balloni. 1986. Consórcio das culturas de feijão (Phaseolus vulgaris L) e eucalipto (Eucalyptus grandis W Hill ex Maiden) no sudeste do Brazil. EMBRAPA-CNPF, Boletim de Pesquisa Florestal 12: 83-104. 
Siqueira, J.D.P. 1990. Planejamento e economia do recurso florestal Anais do $6^{\circ}$ Congresso Florestal Brasileiro, Campos do Jardão. SBS (1): $15-18$.

Soresini, L. 1993. Benefícios sociais e econômicos da pesquisa florestal. Anais do I Simpósio Brasileiro de Pesquisa Florestal. SIF 300305.

Spinelli, P. 1993. Modelo de reflorestamento desenvolvido pela Ferrovia Paulista S.A., visando o aproveitamento da madeira de eucalipto, para produção de dorementes, postes e afins. Anais do I Simpósio Brasileiro de Pesquisa Florestal. SIF 250-254.

Suchek, V.I. 1991. The role of the planted forest in the pulp and paper industry in Brazil. For. Chron. 67(6): 636-648.
Swioklo, M.T. 1990. Legislação florestal: evolução e avaliação. Anais do $6^{\circ}$ Congresso Florestal Brasileiro. Campos do Jordão. SBS (1): $55-58$.

Tristão, R.A. 1992. Classificação ecológica de uma area do Estado de Minas Gerais: um método biopedológico. (M.S. thesis). Universidade Federal de Viçosa, Imprensa Universitária. 91 p.

Van Goor, C.P. 1985. The impact of tree species on soil productivity. Neth. J. Agric. Sci., 33: 133-140.

Worrel, A.C. 1959. Economics of American forestry. John Wiley \& Sons, New York. 441 p.

Willis, E.G. 1980. Allelopathy and its role in forests of Eucalyptus regnans $\mathrm{F}$. Muell. (Ph.D. Thesis). University of Melbourne, Australia. 